\title{
UPAYA PENINGKATAN KARAKTER SISWA SMA DALAM PERMAINAN BOLA BASKET MELALUI MODEL TPSR
}

\section{THE EFFORTS TO IMPROVE CHARACTERS OF SENIOR HIGH SCHOOL STUDENTS IN BASKETBALL GAME THROUGH TPSR MODEL}

\author{
Titis Nurina, Pamuji Sukoco \\ SMA Muhammadiyah 3 Yogyakarta, Universitas Negeri Yogyakarta \\ titis_bisa@yahoo.com,pamuji_sukoco@uny.ac.id
}

\begin{abstract}
Abstrak
Pembelajaran pendidikan jasmani dalam model TPSR lebih menekankan pada kondisi siswa dan pendekatannya juga berorientasi kepada aktualisasi diri dan rekonstruksi sosial siswa di dalam pembelajaran permainan bola basket. Penelitian ini bertujuan untuk meningkatkan karakter tanggung jawab, kerja sama, dan percaya diri siswa putri kelas XI IPS 2 SMA Muhammadiyah 3 Yogyakarta dengan model TPSR dalam pembelajaran permainan bola basket. Penelitian ini menggunakan metode penelitian tindakan kelas yang dilaksanakan dalam dua siklus. Subjek dalam penelitian adalah seluruh siswa putri kelas XI IPS 2 SMA Muhammadiyah 3 yang berjumlah sembilan siswa. Analisis data menggunakan analisis diskriptif, kualitatif, dan kuantitatif. Hasil penelitian menunjukkan bahwa model pembelajaran TPSR dapat meningkatkan karakter tanggung jawab dan kerja sama dalam pembelajaran permainan bola basket yang berdampak pada kepercayaan diri siswa putri kelas XI IPS 2 SMA Muhammadiyah 3 Yogyakarta yang dapat dilihat dari peningkatan nilai keterampilan psikomotor, kognitif, dan afektif siswa.
\end{abstract}

Kata Kunci: TPSR, karakter, permainan bola basket

\begin{abstract}
The teaching of physical education in the TPSR model emphasizes more on students' conditions and the approach is also oriented toward self-actualization and social reconstruction of the students in teaching the game of basketball. This study aims to improve the characters of responsibility, cooperation, and self-confidence of female students of class XI IPS 2 SMA Muhammadiyah 3 Yogyakarta with the TPSR model in teaching the game of basketball. This study was a classroom action research carried out in two cycles. The subjects were all female students of class XI IPS 2 SMA Muhammadiyah 3 , totaling nine students. The data were analyzed using the descriptive qualitative quantitative analysis technique. The results show that the TPSR teaching model can improve the characters of responsibility and cooperation in teaching the game of basketball that has an impact on the confidence of female students in class XI IPS 2 SMA Muhammadiyah 3 Yogyakarta which can be seen from the increase in the score in psychomotor, cognitive, and affective skills.
\end{abstract}

Keywords: TPSR, characters, basketball game 


\section{Pendahuluan}

Bangsa Indonesia memerlukan sumber daya manusia dalam jumlah dan mutu yang memadai sebagai penggerak pembangunan. Dari sisi jumlah, penduduk Indonesia memiliki usia produktif yang telah mencukupi, namun dari mutu dan kualitas perlu ditingkatkan. Sumber daya manusia yang berkualiatas memiliki kapabilitas yang mencakup pengetahuan dan keterampilan yang cukup serta memiliki karakter yang kuat agar ilmu dan keterampilan yang dimiliki dapat berguna. Pendidikan nasional berfungsi mengembangkan kemampuan dan membentuk watak serta peradaban bangsa yang bermartabat dalam rangka mencerdaskan kehidupan bangsa, bertujuan untuk berkembangnya potensi peserta didik agar menjadi manusia yang beriman dan bertakwa kepada Tuhan Yang Maha Esa, berakhlak mulia, sehat, berilmu, cakap, kreatif, mandiri, dan menjadi warga negara yang demokratis serta bertanggung jawab (UU no. 20 Tahun 2003 tentang Sistem Pendidikan Nasional). Dari fungsi dan tujuan tersebut, terdapat dua hal yang penting untuk diwujudkan oleh lembaga pendidikan yaitu, mengembangkan kemampuan dan membangun watak.

Pendidikan jasmani merupakan bagian integral dari pendidikan secara keseluruhan, sehingga pendidikan jasmani memiliki arti yang cukup representatif dalam mengembangkan manusia dalam persiapannya menuju manusia yang seutuhnya. Pendidikan jasmani merupakan suatu proses seseorang sebagai individu maupun anggota masyarakat yang dilakukan secara sadar dan sistematik melalui berbagai kegiatan dalam rangka memperoleh kemampuan, keterampilan jasmani, pertumbuhan, kecerdasan, dan pembentukan karakter. Menurut Menteri Negara Pemuda dan Olahraga, Andi Alfian Mallarangeng, bahwa pendidikan jasmani dan olahraga di Indonesia belum diimplementasikan secara baik dan efektif dalam proses pendidikan karakter. Hingga saat ini, harapan masih tinggal harapan karena pendidikan jasmani dan olahraga masih belum mampu mengusung peranannya yang demikian ideal karena berbagai kelemahan yang masih membelit dari waktu ke waktu (Lena, 2011).

Pendidikan jasmani merupakan suatu proses seseorang sebagai individu maupun anggota masyarakat yang dilakukan secara sadar dan sistematik melalui berbagai kegiatan dalam rangka memperoleh kemampuan dan keterampilan jasmani, pertumbuhan, kecerdasan, dan pembentukan watak. Pada hakikatnya pendidikan jasmani adalah proses pendidikan yang memanfaatkan aktivitas jasmani untuk menghasilkan perubahan holistik dalam kualitas individu, baik dalam hal fisik, mental, serta emosional. Pendidikan jasmani memberikan tekanan pembelajaran tidak hanya pada aspek psikomotor dan kognitif semata, akan tetapi menekankan pula pada aspek afektif dan sosial. Secara realistis memang dapat dimengerti bahwa nilainilai pendidikan jasmani yang menyeluruh pada perkembangan siswa tidak dapat lepas dari koridor tiga domain yaitu kognitif, afektif, dan psikomotor.

Tantangan pembelajaran pendidikan jasmani terletak dalam struktur program aktivitas jasmani siswa dan umumnya berfokus hanya pada pengembangan keterampilan fisik serta kurangnya model yang diberikan guru maupun pelatih dalam mengimplementasikannya nilai-nilai yang terkandung di dalam pembelajaran. Menurut Rahman (2011, p.40) dalam kajian keterlaksanaan pendidikan jasmani dan olahraga di DIY, salah satu masalah kritis yang terjadi adalah terlalaikannya pembinaan terhadap domain kognitif (misalnya aspek penalaran dan kemampuan memecahkan masalah dan ranah afektif terutama aspek pendidikan watak (misalnya self esteem, respect dan responsibility).

Seharusnya siswa dapat lebih banyak terpengaruh oleh pengalaman aktivitas jasmani dalam olahraga tersebut. Aktivitas jasmani adalah pergerakan anggota tubuh yang menyebabkan pengeluaran tenaga yang sangat penting bagi pemeliharaan kesehatan fisik dan mental, serta mempertahankan kualitas hidup agar tetap sehat dan bugar sepanjang hari. Siswa yang berpartisipasi dalam kegiatan fisik setiap hari menunjukkan meningkatkan daya ingat, konsentrasi, dan komunikasi, pemecahan masalah, dan kemampuan kepemimpinan, kreativitas bahkan dapat meningkatkan pembelajaran di bidang studi lainnya walaupun kegiatan tersebut akan mengurangi waktu untuk mempelajari materi akademik (Mahfudin: 2010).

Struktur materi pendidikan jasmani untuk SMA meliputi teknik atau keterampilan dasar permainan olahraga bola basket, bolavoli, sepakbola, softball, bulutangkis, senam, aktivitas ritmik, akuatik, kecakapan hidup di alam terbuka, dan kecakapan hidup personal, kebugaran jasmani serta pembentukan sikap dan perilaku. Seperti yang tertera pada standar kompetensi dan kompetensi dasar pendidikan jas- 
mani SMA, yaitu mempraktikkan berbagai teknik dasar ke dalam permainan dan olahraga serta nilai-nilai yang terkandung di dalamnya. kompetensi dasar dari standar kompetensi tersebut adalah mempraktikkan variasi dan kombinasi teknik dasar salah satu permainan dan olahraga beregu bola besar meliputi bola basket, sepakbola, bolavoli lanjutan dengan konsisten serta nilai kerja sama, toleransi, percaya diri, keberanian, menghargai lawan dan bersedia berbagi tempat dan peralatan. Di dalam Kompetensi Dasar tersebut digunakan oleh guru sebagai acuan materi pembelajaran yang akan diberikan telah disebutkan juga nilai-nilai yang terkandung dalam materi tersebut. Untuk mengembangkan pembelajaran yang efektif agar standar kompetensi dan kompetensi dasar tercapai, guru pendidikan jasmani harus memahami dan memperhatikan karakteristik dan kebutuhan siswa. Dengan memahami karakteristik perkembangan siswa, guru akan mampu membantu siswa belajar secara efektif.

SMA Muhammadiyah 3 Yogyakarta memiliki 21 kelas parallel yang terdiri dari 7 kelas X, XI Program IPA-IPS, dan XII Program IPA-IPS. Rata-rata jumlah siswa perkelas adalah 35-38 siswa. Pembagian kelas di SMA Muhammadiyah 3 Yogyakarta ditentukan dengan rangking akademik siswa dari kelas X-A sampai X-G, XI dan XII Program IPA 1, IPA 2, IPA 3, IPA 4 sampai dengan IPS 1, IPS 2, IPS 3. Dalam setiap kelas memiliki tingkatan nilai akademik tinggi, sedang dan kurang. Pada kelas-kelas yang termasuk kategori kurang dalam nilai akademik memiliki beberapa permasalahan dalam pelaksanaan pembelajaran seperti banyak yang tidak tuntas nilai KKM dan sulit dikondisikan pada saat proses belajar di dalam kelas, tugas tidak terselesaikan pada waktunya dapat diamati ketika akhir semester 1, rasa tanggung jawab terhadap pembelajaran sangat kurang. Hal ini ternyata terjadi di dalam proses pembelajaran mata pelajaran lainnya. Berdasarkan hasil observasi keseharian dan hasil jejak pendapat kepada guru-guru mata pelajaran lain yang mengajar di kelas tersebut juga berpendapat sama.

Kasus yang sering muncul dalam proses pembelajaran pendidikan jasmani dalam kelas XI IPS 2 khususnya siswa putri dari aspek pencapaian nilai ulangan praktek masih di bawah KKM seperti pada materi permainan bola basket dan atletik. Rata-rata nilai permainan bola basket siswa pada semester 1 adalah 61,67 sehingga memerlukan beberapa kali pengulang- an untuk mendapatkan nilai yang tuntas atau memenuhi kriteria ketuntasan. Hal ini dikarenakan ketika guru menerangkan dan mempraktikkan materi pembelajaran beberapa siswa tidak memperhatikan seperti mengobrol dan bercanda dengan teman, kurang berani dalam mempraktikkan sendiri atau malu-malu, tidak bersemangat dalam melakukan materi permainan beregu atau berkelompok seperti tidak mau merebut bola ketika sudah kalah bertanding, masih kurang saling mendukung antar teman, sering berperilaku individual dan tidak sesuai dengan perintah guru, rasa tanggung jawab siswa terhadap tugas yang diberikan guru juga masih sangat kurang dan belum banyak saling berinteraksi antara siswa satu dengan yang lainnya.

Berdasarkan dari tujuan pendidikan jasmani dan permasalahan yang dihadapi dalam pembelajaran pendidikan jasmani di kelas XI IPS 2 SMA Muhammadiyah 3 Yogyakarta tersebut peneliti mencoba meneliti dengan menggunakan model pembelajaran Teaching Personal and Social Responsibility (TPSR) yang terkenal dengan Model Hellison. Model pembelajaran ini merupakan suatu proses pembelajaran yang mengondisikan siswa untuk berinteraksi dan mempelajari bagaimana belajar. Model TPSR menekankan usaha dan pengarahan diri sendiri yang penting bagi pencapaian kesejahteraan personal. Menghormati hak-hak serta mempertimbangkan perasaan orang lain, dan peduli tentang orang lain sangat penting untuk pencapaian kesejahteraan sosial siswa.

Tanggung jawab pada taraf yang paling rendah adalah kemampuan seseorang untuk menjalankan kewajiban karena dorongan dari dalam diri atau bisa disebut dengan panggilan jiwa (Munir, 2010, p.90). Tanggung jawab akan tumbuh jika siswa memiliki dorongan yang kuat. Hal ini terjadi karena keterkaitan emosi dan pemahaman yang cukup terhadap realitas sekitarnya. Model pembelajaran tanggung jawab diri dan sosial, memberdayakan siswa untuk lebih bertanggung jawab atas tindakan siswa, serta mengajarkan kepada siswa untuk menjadi lebih peka tentang hak, perasaan, dan kebutuhan orang lain.

Proses tanggung jawab merupakan sebuah mekanisme yang harus dipikul bersama dengan bekerja sama dengan orang lain. Tanggung jawab tidak menjadi milik satu pribadi individu, tetapi juga milik semua anggota kelompok sosial. Menurut Tjiharjadi (2007, p.217) tanggung jawab adalah buah positif yang dihasilkan dari beban yang harus dicapai dalam 
proses pencapaian tujuan. Tanpa ada tanggung jawab, tidak akan ada hasil pencapaian yang optimal dan mendukung peningkatan kemampuan anggota kelompok. Model ini berusaha untuk membantu siswa merasa diberdayakan, untuk mengalami membuat komitmen untuk diri sendiri dan orang lain, untuk hidup dengan seperangkat prinsip, dan khawatir tentang kesejahteraan orang lain. Model TPSR menekankan usaha dan pengarahan diri sendiri yang penting bagi pencapaian kesejahteraan personal. Menghormati hak-hak, mempertimbangkan perasaan orang lain, dan peduli tentang orang lain sangat penting untuk pencapaian kesejahteraan sosial. Dengan bertambahnya usia seorang anak, maka konsep diri dalam kesejahteraan sosial juga akan terus berkembang melalui interaksi sosial baik terhadap orangtua, orang lain dan teman sebayanya. Semenjak konsep diri mulai terbentuk, siswa akan berperilaku sesuai dengan konsep diri tersebut. Pandangan siswa pada dirinya sendiri akan menentukan tindakan yang akan diperbuat.

Menurut Susana (2006, p.19) seseorang memiliki konsep diri yang positif, maka akan terbentuk penghargaan yang tinggi terhadap diri sendiri. Penghargaan terhadap diri yang merupakan evaluasi terhadap diri sendiri akan menentukan sejauh mana seseorang yakin akan kemampuan dirinya. Jadi, apabila siswa memiliki konsep diri yang positif yang ditunjukkan melalui penghargaan terhadap diri, segala perilakunya akan selalu tertuju kepada keberhasilan. Hellison menempatkan pencapaian hasil ini dalam perkembangan informal tingkat atau tujuan. Hal ini membantu para guru dan siswa untuk menjadi sadar akan perilaku dan untuk memfokuskan upaya untuk menuju hasil yang diinginkan. Guru dapat menggunakan tingkat sebagai kerangka kerja untuk merencanakan, mengajar, dan mengevaluasi pembelajaran siswa.

Tingkat model TPSR dapat digambarkan sebagai bergerak dari tidak bertanggung jawab untuk tanggung jawab, bergerak dari rasa hormat untuk diri sendiri dan untuk menghormati dan kepedulian terhadap orang lain. Perilaku ini akan pertama kali dikembangkan dalam kelas pendidikan jasmani dan kemudian digunakan di luar kelas, dalam pengaturan rumah dan masyarakat. Diperkuat oleh teori Erik Erikson menyatakan bahwa masyarakat memainkan peran yang sangat penting dalam perkembangan psikososial individu. Peranan ini dimulai dari aturan atau budaya masyarakat sampai pola asuh orangtua (Eka, 2008, p.23).

Hellison membuat 5 tingkatan dalam model pembelajarannya yaitu "Level 0 Irresponsibility, Level I Respect, Level II Participation, Level III Self Direction, Level IV Caring" (Hellison, 2003, pp.28-35). Tingkat nol adalah tingkatan awal sebelum adanya rekonstruksi sosial. Siswa yang beroperasi pada tingkat nol ini membuat alasan, menyalahkan orang lain atas perilaku siswa, dan menolak tanggung jawab pribadi atas apa yang dilakukan atau tidak lakukan.

Peneliti akan menggunakan materi pembelajaran permainan bola basket karena selain dengan kondisi pada semester 1 , siswa kelas XI IPS 2 tersebut memiliki hambatan pembelajaran dalam materi permainan bola basket, materi ini sangat sesuai dengan SK dan KD yang menjadi acuan materi pembelajaran permainan bola basket pendidikan jasmani SMA yang di dalam pembelajaran tersebut mengandung unsur permainan tim atau kelompok. Adapun indikator pencapaian SK dan KD materi bola basket adalah melakukan latihan koordinasi teknik dasar melempar, menangkap, menggiring dan menembak bola (berpasangan dan berkelompok) dengan koordinasi yang baik. Bermain bola basket dengan menggunakan peraturan yang dimodifikasi untuk menumbuhkan dan membina nilai-nilai tanggung jawab, kerja sama, kejujuran, menghargai, semangat, dan percaya diri.

Sebelumnya guru menggunakan metode demonstrasi, cakupan dan bermain dalam proses pembelajaran permainan bola basket yang menyebabkan siswa bermain-main saja dan kurang memperhatikan nilai-nilai kerja sama dan tanggung jawab sebagai sebuah kelompok sehingga tujuan dan hasil pembelajaran kurang tercapai secara maksimal. Maka dari pada itu pada penelitian ini peneliti mengacu pada model pembelajaran yang di kembangkan oleh Hellison, diharapkan dapat memperbaiki pembelajaran dan meningkatkan kerja sama dan tanggung jawab serta kepercayaan diri siswa kelas XI IPS 2 tersebut.

\section{Metode}

Jenis Penelitian

Penelitian ini menggunakan pendekatan Penelitian Tindakan Kelas atau Classroom Action Research (CAR). 


\section{Waktu dan Tempat Penelitian}

Penelitian ini dilaksanakan di SMA Muhammadiyah 3 Yogyakarta pada siklus I dilakukan 9 dan 16 Februari 2013. Dari hasil refleksi pada siklus I, penelitian ini membutuhkan siklus II yang dilaksanakan pada 6 dan 13 April 2013.

Target/Subjek Penelitian

Subjek penelitian adalah sumber data dalam penelitian, bisa berupa orang, tempat, maupun simbol. Subjek penelitian ini adalah siswa putri kelas XI IPS 2 SMA Muhammadiyah 3 Yogyakarta tahun ajaran 2012/ 2013 yang berjumlah 9 siswa. Objek penelitian ini adalah peningkatan karakter kerja sama, tanggung jawab dan percaya diri dalam permainan bola basket.

Prosedur

Model penelitian adalah prosedur yang menggambarkan bagaimana penelitian akan dilaksanakan. Dalam penelitian tindakan kelas ini, peneliti menggunakan model spiral Kemmis dan Taggart. Model Kemmis dan Mc Taggart, setiap siklus menggunakan empat komponen tindakan yaitu perencanaan, tindakan, observasi, dan refleksi dalam suatu spiral yang saling terkait. Gambar 1 berikut ini adalah model spiral Kemmis dan Mc Taggart yang dikutip oleh Koshy (2010, p.5):

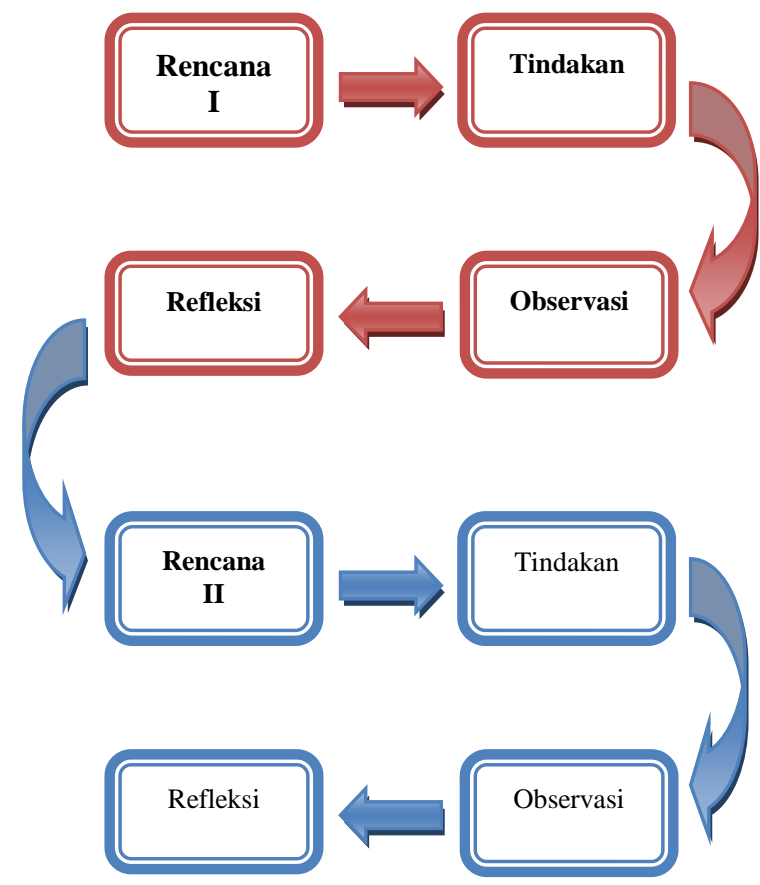

Gambar 1. Model Penelitian Kemmis dan Mc Taggart (2000, p.565)
Data, Instrumen, dan Teknik Pengumpulan Data

Instrumen dalam penelitian ini adalah sebagai berikut:

$R P P$

Merupakan perangkat pembelajaran yang digunakan sebagai pedoman pada proses pembelajaran.

\section{Lembar Observasi}

Merupakan instumen yang berupa isian tentang hasil observasi selama tindakan berlangsung yang akan diisi oleh kolaborator sebagai pengamat (observer). Lembar ini berupa daftar informasi keterlaksanaan rencana pelaksanaan pembelajaran dan informasi belajar siswa.

\section{Catatan Lapangan}

Catatan lapangan digunakan untuk mencatat segala kejadian selama proses pembelajaran berlangsung.

\section{Dokumentasi}

Metode ini digunakan untuk mengungkapakan data-data yang bersifat dokumenter atau tertulis, terpampang, dan dapat dibaca seperti presensi, data pribadi, dan daftar nilai. Instrumen dokumentasi digunakan untuk memberi gambaran secara konkret mengenai aktivitas siswa pada saat proses pembelajaran berlangsung dan untuk memperkuat data yang diperoleh.

\section{Jenis Tindakan}

Berdasarkan model desain PTK dari Kemmis \& Mc Taggart penelitian ini dilaksanakan dalam dua siklus dan setiap siklus menggunakan pembelajaran permainan bola basket dengan model TPSR. Pada setiap siklus diadakan penilaian untuk mengetahui perkembangan pemahaman karakter kerja sama, tanggung jawab dan percaya diri dalam permainan bola basket siswa. Secara lebih rinci prosedur penelitian tindakan kelas dapat dirumuskan sebagai berikut:

\section{Siklus I}

\section{a. Perencanaan}

Pada tahap perencanaan ini peneliti dan kolabolator berdiskusi tentang perencanaan tindakan yang berdasar pada masalah-masalah yang terjadi di dalam pembelajaran, kemudian 
peneliti menyusun perangkat pembelajaran dan instrumen, yaitu: (1) Rencana Pelaksanaan Pembelajaran (RPP) dengan pembelajaran permainan bola basket yang akan digunakan oleh peneliti sebagai pedoman dalam pelaksanaan pembelajaran tentang belajar pemahaman karakter kerja sama, tanggung jawab dan percaya diri dalam permainan bola basket siswa. RPP disusun oleh peneliti dengan mendapat pertimbangan dari pembimbing dan guru kolabolator, (2) Lembar observasi keterlaksanaan kegiatan pembelajaran dengan model TPSR yang telah dituangkan dalam RPP, (3) Lembar observasi implementasi pemahaman siswa, (4) Lembar evaluasi diri siswa.

\section{b. Tindakan dan observasi}

\section{1). Tindakan}

Selama proses pembelajaran berlangsung, guru mengajar siswa dengan menggunakan RPP yang telah dibuat oleh peneliti dengan guru sebelumnya. Dalam pelaksanaan tindakan dilakukan dengan fleksibel dan terbuka dalam artian pelaksanaan kegiatan pembelajaran tidak harus terpaku sepenuhnya pada RPP, akan tetapi dalam kegiatan pembelajaran dapat dilakukan perubahan-perubahan yang sekiranya diperlukan. Selama proses pembelajaran peneliti dibantu oleh dua orang pengamat untuk mengamati siswa dan guru di kelas.

\section{2). Observasi}

Observasi atau pengamatan merupakan upaya mengamati pelaksanaan tindakan. Observasi terhadap proses tindakan yang dilaksanakan bertujuan untuk mendokumentasikan keterlaksanaan pembelajaran yang dituangkan dalam rencana tindakan, pengaruh tindakan yang berorientasi pada masa yang akan datang, dalam hal ini adalah kegiatan selanjutnya, serta digunakan sebagai dasar untuk kegiatan refleksi yang lebih kritis. Kegiatan observasi dilaksanakan bersamaan dengan proses pembelajaran. Hal yang dicatat dalam kegiatan observasi ini antara lain proses tindakan, pengaruh tindakan yang disengaja maupun yang tidak disengaja, situasi tempat dan tindakan, dan kendala yang dihadapi. Semua hal tersebut dicatat dalam kegiatan observasi yang terencana secara fleksibel dan terbuka. Untuk mengetahui apakah proses pembelajaran yang dilakukan sesuai dengan skenario yang telah disusun bersama, perlu dilakukan evaluasi. Selain itu juga bertujuan untuk mengetahui tingkat ketercapaian sasaran pembelajaran yang diharapkan.

\section{c. Refleksi}

Refleksi merupakan bagian yang sangat penting untuk memahami dan memberikan makna terhadap proses dan hasil pembelajaran yang terjadi yang dilakukan dengan: (a) pada saat memikirkan tindakan yang akan dilakukan (b) ketika tindakan sedang dilakukan, dan (c) setelah tindakan dilakukan, adapun kegiatan yang dilakukan pada saat merefleksi, melakukan analisis, dan mengevaluasi atau mendiskusikan data yang harus diperoleh, penyusunan rencana tindakan yang hasilnya diperoleh melalui kegiatan observasi. Data yang telah dikumpulkan dalam observasi harus secepatnya dianalisis atau diinterprestasikan (diberi makna) sehingga dapat segera diberi tindakan yang dilakukan untuk mencapai tujuan, jika diinterprestasikan data tersebut belum mencapai tujuan yang diharapkan maka peneliti dan observer melakukan langkah-langkah perbaikan untuk diterapkan pada siklus selanjutnya. Akan tetapi jika pada pelaksanaan refleksi terhadap hal-hal dianggap baik, maka hal yang baik tersebut harus terus digali.

Keempat komponen penelitian tindakan tersebut yang berupa rangkaian tersebut dipandang sebagai satu siklus. Oleh karena itu, pengertian siklus pada hal ini ialah suatu putaran kegiatan yang terdiri dari perencanaan (planning), tindakan (acting), pengamatan (observing), dan refleksi (reflecting). Keputusan untuk menghentikan atau melanjutkan siklus merupakan keputusan bersama antara peneliti dan kolaborator. Siklus dihentikan jika peneliti dan kolaborator sepakat bahwa pembelajaran pemahaman karakter kerja sama, tanggung jawab dan percaya diri dalam permainan bola basket yang dilakukan sudah sesuai dengan rencana dan telah mampu meningkatkan prestasi belajar siswa.

\section{Teknik Analisis Data}

Data yang telah diperoleh di lapangan kemudian dianalisis dengan menggunakan analisis deskriptif. Analisis data dalam penelitian ini dilakukan dengan cara peneliti bersama kolaborator merefleksi hasil observasi terhadap proses pembelajaran yang dilaksanakan oleh guru dan siswa di dalam kelas. Data kualitatif dalam catatan lapangan diolah menjadi kalimatkalimat yang bermakna dan dianalisis secara kuantitatif. Teknik analisis data yang digunakan 
secara berturutan yaitu reduksi data, penyajian data dan penarikan kesimpulan.

Reduksi data dalam penelitian ini meliputi penyeleksian data melalui ringkasan atau uraian singkat dan pengolahan data ke dalam pola yang lebih terarah. Dengan demikian reduksi data merupakan suatu bentuk analisis yang menajamkan, menggolongkan, mengarahkan, membuang yang tidak perlu dan mengorganisasi data dengan cara sedemikian rupa sehingga kesimpulan finalnya dapat ditarik dan diverifikasi. Penyajian data dilakukan dalam rangka mengorganisasikan data yang merupakan penyusunan informasi secara sistematis dari hasil reduksi data mulai dari perencanaan tindakan, observasi dan refleksi pada masing-masing siklus. Penarikan kesimpulan merupakan upaya pencarian makna data. Data yang terkumpul disajikan secara sistematis dan perlu diberi makna.

Dalam PTK ini juga dilakukan teknik analisis data dengan: membandingkan kesesuaian rencana pembelajaran yang telah didiskusikan antara peneliti dengan kolabolator dengan pelaksanaan di lapangan dengan cara dicatat dalam lembar obsevasi guru. Dampak dari penerapan pembelajaran model TPSR ini terhadap kondisi siswa selama proses belajar mengajar berlangsung, selanjutnya dicatat dalam lembar observasi siswa, menganalisis hasil rekaman video, dan menganalisis hasil pengamatan tentang keterampilan siswa dalam melakukan permainan bola basket. Keempat analisis data ini dilakukan dengan teliti dan cermat agar dapat ditarik kesimpulan dengan benar. Selain itu juga dilakukan analisis dengan cara membandingkan hasil dari angket pembelajaran dan evaluasi diri siswa. Hal ini dilakukan untuk mengetahui tingkat kemajuan pemahaman siswa dalam mengikuti pembelajaran permainan bola basket setelah mengikuti pembelajaran permaianan bola basket dengan model TPSR.

\section{Hasil Penelitian dan Pembahasan}

Hasil penelitian diawali peneliti dengan melakukan observasi terhadap proses pembelajaran pendidikan jasmani dan hasil belajar pada materi permainan bola basket pada siswa putri kelas XI IPS 2 SMA Muhammadiyah 3 Yogyakarta, dalam observasi tersebut ditemukan bahwa dalam proses pembelajaran jasmani siswa masih kurang antusias, bersemangat, serius serta belum memahami nilai kerja sama dan tanggung jawab dalam sebuah kelompok yang seharusnya diperoleh dalam pembelajaran permainan bola basket. Adapun indikator kondisi siswa seperti berikut: (1) Siswa masih banyak bercanda dan mencela dalam melakukan permainan, (2) Siswa masih selalu menunggu perintah guru untuk melakukan gerakan saat permainan berlangsung, (3) Beberapa siswa masih bermain secara individu dalam melaksanakan permainan, sedangkan yang lain hanya melihat dan tidak mau berkompetisi, (4) Belum adanya saling memberi dukungan dan komunikasi di dalam kelompok masing-masing untuk mencapai sebuah kemenangan.

Hasil proses pembelajaran permainan bola basket dalam bentuk kuantitatif masih belum mencapai Kriteria Ketuntasan Minimal (KKM). Berdasarkan hasil nilai awal siswa 22,22\% (2 anak) dari 9 anak yang memperoleh ketuntasan minimal dalam pembelajaran permainan bola basket. Untuk mengatasi hal tersebut selanjutnya peneliti melakukan upaya peningkatan karakter kerja sama dan tanggung jawab dalam pembelajaran permainan bola basket dengan pendekatan model pembelajaran TPSR (Teaching Personal Social and Responsibility) pada siswa putri kelas XI IPS 2 SMA Muhammadiyah 3 Yogyakarta agar siswa lebih mengerti, memahami dan dapat meningkatkan karakter kerja sama, tanggung jawab dan percaya diri yang dimiliki siswa. Penelitian ini direncanakan dengan 1 siklus, tetapi setelah dilaksanakan ternyata membutuhkan siklus ke 2 . Setiap siklus terdiri dari 2 kali pertemua. Pada akhir setiap pertemuan selalu dilakukan evaluasi pembelajaran permainan bola basket.

Secara keseluruhan untuk peningkatan nilai hasil pembelajaran permainan bola basket dapat dilihat pada tabel 1 dan diagram berikut ini:

Tabel 1. Nilai Keterampilan Permainan Bola Basket Siswa

\begin{tabular}{cccccc}
\hline \multirow{2}{*}{ Aspek } & \multirow{2}{*}{ Awal } & \multicolumn{2}{c}{ Siklus 1 } & \multicolumn{2}{c}{ Siklus 2 } \\
\cline { 3 - 6 } & & P1 S1 & P2 S1 & P1 S2 & P2 S2 \\
\hline Psikomotor & 61,67 & 65,56 & 72,22 & 75,00 & 77,22 \\
Rata-rata & \multicolumn{4}{c}{68,89} & 76.11 \\
Kognitif & 55,56 & 60.00 & 66,67 & 75,56 & 84,44 \\
Rata-rata & \multicolumn{4}{c}{63,33} & 80,00 \\
Afektif & 54,67 & 61,33 & 68,44 & 75,56 & 78,67 \\
Rata-rata & & 64,89 & 77,11 \\
\hline
\end{tabular}




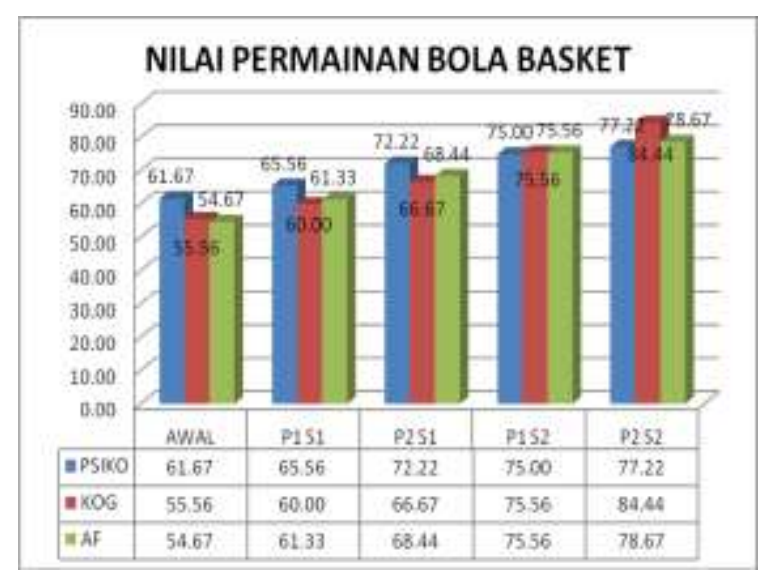

Gambar 2. Diagram Nilai Keterampilan Siswa dalam Permainan Bola Basket

Bedasarkan refleksi dari analisa data yang terkumpul maka hasil penelitian tindakan kelas menunjukkan bahwa akhir siklus ada peningkatan mutu pembelajaran. Hal tersebut dapat dilihat pada data hasil observasi kelas, data hasil observasi terhadap sikap siswa dan data hasil observasi terhadap kemampuan permainan bola basket siswa berikut ini:

Siklus I

Pada siklus I tindakan dalam proses pembelajaran pemahaman kerja sama dan tanggung jawab siswa dalam permainan bola basket dengan model TPSR pada siswa putrid kelas XI IPS 2 SMA Muhammadiyah 3 Yogyakarta sudah berjalan sesuai prosedur dan baik. Pada siklus I, peneliti menggunakan permainan-permainan yang bertujuan untuk menguatkan pemahaman kerja sama dan tanggung jawab di dalam permainan bola basket dari permainan untuk pemanasan, inti pembelajaran dan penutup. Sebelum adanya tindakan ini, siswa dalam pembelajaran permainan bola basket belum memahami bagaimana seharusnya menjalankan permainan.

Setelah diberikan tindakan dengan metode TPSR dalam proses pembelajaran, siswa merasa senang dan mulai memahami bagaimana menjalankan permainan basket dengan kerja sama dan tanggung jawab kelompok dengan tidak melupakan sasaran yang ingin dicapai yaitu siswa dapat melakukan proses teknik gerak dasar permainan bola basket dengan benar. Metode pengajaran telah disesuaikan dengan karakteristik pertumbuhan dan perkembangan siswa, sehingga siswa tidak kesulitan dalam melakukan setiap gerakan dalam permainan tersebut.
Sebelum diberikan tindakan dengan model pembelajaran TPSR hanya 2 siswa dari 9 siswa putri kelas XI IPS 2 yang tuntas KKM. Kemudian setelah diberi tindakan dengan model pembelajaran TPSR, maka peneliti dengan 2 orang kolabolator membandingkan hasil penilaian pembelajaran siswa pada pertemuan pertama dan kedua. Diperoleh data ada peningkatan keterampilan psikomotor siswa dalam pembelajaran permainan bola basket seperti keterampilan koordinasi gerak mengumpan, menangkap, menggiring dan menembak dari pertemuan 1 ke pertemuan 2 dengan rata-rata nilai keterampilan psikomotor siswa pada siklus I adalah 68,89 . Namun beberapa siswa yang masih belum memenuhi kriteria dalam keterampilan gerak menggiring dan menembak bola.

Berdasarkan hasil penilaian proses bermaian bola basket pada siklus I pertemuan 1 nilai rata-rata keterampilan kognitif siswa 60,00 dengan catatan 3 dari 9 siswa telah memenuhi kriteria dan hasil rata-rata nilai pada siklus I ini adalah 63,33. Hasil penilaian pertemuan 2 pada siklus I, nilai rata-rata keterampilan kognitif siswa 66,67 dengan catatan 3 dari 9 siswa telah memenuhi kriteria. Berdasarkan hasil penilaian proses bermain bola basket pada siklus I pertemuan 1 nilai rata-rata keterampilan afektif siswa 61,33 dengan catatan 2 dari 9 siswa telah memenuhi kriteria dalam penilaian keterampilan afektif dengan rata-rata nilai 64,89 pada siklus I ini.

Pada pertemuan 1 ini siswa masih banyak yang belum memenuhi kriteria jujur, kerja sama dan tanggung jawab. Masih banyak siswa yang melanggar peraturan dan menggumpat saat permaian berlangsung, belum berupaya membantu teman dalam satu tim/kelompok untuk memudahkan permainan baik saat menjaga maupun menyerang, belum banyak saling memberikan motivasi dan semangat kepada teman, belum bertanggungjawab mengambil bola ketika bola terlepas dari tangkapan, bertanggung jawab mengerjakan instruksi yang diberikan oleh guru saat permainan berlangsung dan bertanggung jawab atas target yang telah ditentukan dalam kelompok.

Sedangkan hasil penilaian pertemuan 2 pada siklus I, nilai rata-rata keterampilan afektif siswa 68,44 dengan catatan 4 dari 9 siswa telah memenuhi kriteria. Hal tersebut diartikan bahwa adanya peningkatan nilai sikap siswa dalam proses pembelajaran pada siklus I ini. Pada pertemuan 2 ini siswa sudah mulai mengkontrol perilakunya dan mulai muncul sikap kompetitif 
dalam setiap permainan. Perilaku berpartisipasi dan saling membantu dalam permainan bola basket juga sudah mulai muncul walaupun masih beberapa siswa yang melakukannya. Dari hal tersebut diartikan bahwa secara kuantitatif nilai mengalami peningkatan, namun dalam pelaksanaan siswa masih kurang memahami saat mengambil keputusan dalam menembak dan menjaga lawan disaat permainan berlangsung.

Dengan demikian setelah diberi pembelajaran dengan model TPSR ini siswa dapat mulai memahami bentuk kerja sama dan tanggung jawab pribadi terhadap kelompok yang berdampak pada pencapaian tujuan atau hasil yang diperoleh. Hal tersebut juga hampir sama pada hasil jawaban angket siswa dan evaluasi diri siswa. Peneliti menyimpulkan bahwa selama pembelajaran pada siklus I siswa mengalami peningkatan sikap dalam proses permainan bola basket. Meningkatnya perilaku siswa ini dapat dilihat dari jawaban angket awal pertemuan sampai pertemuan 2 pada siklus I terjadi peningkatan pada masing-masing tingkatan yaitu tingkat awal Irresponsibility dimana siswa masih sering membuat alasan-alasan dalam melakukan perintah guru, menyalahkan perbuatan teman atau orang laian, menolak tanggung jawab yang seharusnya dikerjakan meningkat menjadi kadang.

Tingkat pertama dalam tingkatan yang dibuat oleh Hellison adalah respect atau menghormati siswa mulai sering mengendalikan perilaku masing-masing karena ada konsekuensi yang akan didapat dari perilakunya, siswa mulai sering menunjukkan rasa hormat dan toleransi. Pada tingkat kedua participation atau berpartisipasi siswa menunjukkan sikap menghormati terhadap hak orang lain (sesama teman dalam satu tim) dengan memberikan kesempatan teman untuk berpartisipasi dan tidak individual saat bermain bola basket. Siswa sering menerima tantangan-tantangan yang diberikaan pada saat permainan bola basket.

Tingkat ketiga self direction atau pengarahan diri siswa masih terkadang dapat menganalisis kemampuannya baik individu maupaun kelompok dan menyusun strategi dalam berusaha mencapai tujuan dalam kelompok untuk memenangkan permainan. Tingkat keempat carring atau membantu orang lain dan mengembangkan kepedulian terhadap orang lain. Hal ini siswa sudah mulai sering saling memberikan dukungan dalam satu kelompok, membantu dan bekerja sama untuk memenangkan permainan.

\section{Siklus II}

Pada siklus II tindakan dalam proses pembelajaran pemahaman kerja sama dan tanggung jawab siswa dalam permainan bola basket dengan model TPSR pada siswa putri kelas XI IPS 2 SMA Muhammadiyah 3 Yogyakarta sudah lebih baik dan cukup memuaskan. Tindakan yang diberikan pada siklus II ini dengan menambah permainan-permainan yang bertujuan untuk menguatkan pemahaman kerja sama dan tanggung jawab di dalam permainan bola basket dari permainan untuk pemanasan, inti pembelajaran dan penutup.

Pada siklus II ini pemahaman siswa tentang kerja sama dan tanggung jawab dalam menjalankan permainan bola basket berkelompok sudah semakin baik dan koordinasi gerak dasar secara individu pun juga meningkat. Berdasarkan hasil penilaian proses bermain bola basket oleh peneliti pada siklus II pertemuan 1 nilai rata-rata keterampilan psikomotor atau gerak siswa 75 dengan catatan 7 dari 9 anak yang tuntas KKM. Hal tersebut diartikan ada peningkatan keterampilan psikomotor siswa dalam pembelajaran permainan bola basket terlebih pada gerak mengumpan siswa kini lebih berani dan luwes, gerak dasar menembak juga lebih sering dipraktikkan siswa selama pembelajaran berlangsung. Namun dalam gerak dasar menggiring bola basket yang masih belum maksimal.

Hasil penilaian pertemuan 2 pada siklus II, nilai rata-rata keterampilan psikomotor siswa 77,22 dengan catatan 9 anak tuntas KKM semua. Hal tersebut diartikan ada peningkatan keterampilan psikomotor siswa dalam pembelajaran permainan bola basket secara umum keterampilan gerak siswa dalam mengkoordinasikan gerakan mengumpan, menangkap, menggiring dan menembak bola basket dalam permainan sudah baik, memenuhi kriteria-kriteria penilaian dan siswa lebih percaya diri dalam penguasaan koordinasi gerakan teknik dasar bola basket dengan nilai rata-rata 76,11 dalam siklus II ini. Secara lebih khusus memang masih ada beberapa siswa yang belum memenuhi kriteria secara maksimal pada penguasaan gerak menggiring dengan tangan kanan maupun kiri, melecutkan pergelangan tangan dan mengikuti gerakan ke arah ring basket dan menangkap bola dengan satu tangan karena penguasaan teknik dasar ini juga ditunjang dengan tingkat latihan yang intensif diluar pembelajaran. Namun dengan demikian target dari pemberian 
tindakan dalam pembelajaran ini terpenuhi dan hasilnya dapat dikatakan maksimal.

Berdasarkan hasil penilaian proses bermaian bola basket pada siklus II pertemuan 1, nilai rata-rata keterampilan kognitif siswa 75,56 dengan catatan 7 dari 9 siswa telah memenuhi kriteria. Hal ini dapat diartikan bahwa ada peningkatan pemahaman siswa dalam melakukan permainan bola basket dalam pembelajaran ini. Keterampilan siswa lebih baik dari pembelajaran sebelumnya, dalam pertemuan ini pengambilan keputusan saat memberikan umpan yang tepat, pengambilan keputusan menangkap bola dengan cepat dan pengambilan keputusan untuk merebut bola sangat terlihat dalam permainan bola basket.

Hasil penilaian peretemuan 2 pada siklus II, nilai rata-rata keterampilan kognitif siswa 84,44 dengan catatan semua anak memenuhi kriteria namun hanya 2 siswa yang mampu menunjukkan keterampilan melebihi kriteria ketuntasan. Rata-rata nilai siswa dalam siklus II ini adalah 80,00. Kedua siswa ini lebih mampu dalam pengambilan keputusan mencari posisi saat menembah dan pengambilan keputusan untuk merebut bola dari lawan. Namun secara keseluruhan siswa dapat memenuhi kriteria penilaian dalam mengambil keputusan saat memberikan umpan dengan tepat, menangkap bola dengan cepat dan menjaga lawan.

Berdasarkan hasil penilaian proses bermain bola basket pada siklus II pertemuan 1 nilai rata-rata keterampilan afektif siswa 75,56 dengan catatan 7 dari 9 siswa telah memenuhi kriteria dalam penilaian afektif. Pada pertemuan 1 siklus II ini siswa mengalami peningkatan dalam kriteria jujur, kerja sama dan tanggung jawab. Sudah banyak siswa yang mampu mengendalikan perilaku seperti mengumpat pada saat permainan berlangsung, mengakui perbuatan jika siswa melakukan pelanggaran, banyak siswa saling membantu teman satu kelompoknya untuk memudahkan saat menjaga maupun menyerang pertahanan lawan, berupaya menjalankan tugas sesuai kesepakatan kelompok masing-masing.

Hasil penilaian pertemuan 2 pada siklus II ini nilai rata-rata keterampilan afektif siswa 78,67 dengan catatan semua siswa telah memenuhi KKM. Rata-rata nilai afektif siswa dalam siklus II ini adalah 77,11. Pada siklus II ini siswa lebih terlihat antusias dalam permainan bola basket, siswa lebih berkompetitif terhadap kelompok lawan, kerja sama antaranggota kelompok secara umum banyak mengalami peningkatan seperti saling memotivasi saat permainan, saling membantu untuk menjaga maupun menyerang, saling berusaha untuk memasukkan bola sebanyak-banyaknya untuk mencapai target yang telah disepakati oleh kelompok dan mengerjakan instruksi yang diberikan oleh guru saat permainan berlangsung.

Berdasarkan jawaban siswa tersebut maka peneliti menyimpulkan bahwa selama pembelajaran pada siklus II ini siswa mengalami peningkatan sikap dalam proses permainan bola basket. Meningkatnya perilaku siswa ini dapat dilihat dari hasil jawaban angket pada pertemuan siklus I sampai akhir siklus II tersebut. Peningkatan terjadi pada jawaban tingkat awal Irresponsibility di mana siswa jarang membuat alasan-alasan dalam mengerjakan perintah guru, jarang dalam menyalahkan orang lain, jarang menolak tanggung jawab yang diberikan oleh guru dan kelompok.

Dalam tingkat pertama respect atau menghormati siswa selalu dapat menunjukkan rasa hormat terhadap teman, selalu dapat memahami hak untuk berpartisipasi dan dampak perilaku terhadap orang lain. Pada tingkat kedua participation atau berpartisipasi siswa menunjukkan sikap selalu menerima tantangantantangan yang diberikan dalam pembelajaran permainan bola basket. Tingkat ketiga self direction atau pengarahan diri siswa selalu dapat menganalisis serta mengukur kemampuan individu maupun kelompok secara realistis, menyusun strategi dalam berusaha mencapai tujuan dalam kelompok untuk memenangkan permainan. Tingkat keempat carring, siswa selalu membantu teman dalam kelompok untuk bertangung jawab dalam mencapai target yang ditentukan oleh kelompok masing-masing dan mengembangkan kepedulian terhadap orang lain seperti selalu memberikan motivasi kepada teman.

Berdasarkan hal tersebut peneliti dengan kolabolator membandingkan hasil penilaian pembelajaran permainan bola basket pada siklus I dan II. Dari dua penjelasan proses kegiatan setiap siklus yaitu siklus I dan II, menunjukkan bahwa hasil observasi, angket dan hasil belajar siswa dalam pembelajaran permainan bola basket selalu ada peningkatan yang baik. 


\section{Simpulan dan Saran}

Simpulan

Terdapat peningkatan karakter kerja sama dan tanggung jawab siswa dalam permainan bola basket yang dapat dilihat pada peningkatan nilai keterampilan afektif dalam pembelajaran dari siklus I ke siklus II sebesar 18,83\%. Indikator peningkatan karakter kerja sama dan tanggung jawab siswa sebagai berikut: (1) Siswa bersegera menempatkan diri pada posisi yang telah ditentukan dalam permainan, (2) Berupaya memasukkan bola sebanyak-banyaknya dengan bentuk kerja sama kelompok, (3) Berupaya untuk menjalankan tugas sesuai yang telah disepakati oleh kelompok, (4) Siswa dapat memosisikan diri sesuai dengan tugas yang dibagi oleh masing-masing kelompok baik pada saat penjagaan maupun penyerangan, (5) Siswa berusaha mencapai target yang sudah disepakati oleh kelompok, (6) Siswa menyelesaikan permainan sesuai yang diminta oleh guru.

Dari peningkatan karakter kerja sama dan tanggung jawab siswa dalam permainan bola basket berdampak pada kepercayaan diri siswa dalam mempraktikan teknik dasar bola basket dan permainan dalam kelompok dilihat dari hasil penilaian keterampilan psikomotor siswa pada siklus I dan siklus II meningkat menjadi $10,48 \%$.

Pemahaman siswa dalam memraktikan permainan bola basket dalam kelompok juga meningkat dari siklus I dan siklus II sebesar 26, $32 \%$ dengan melihat penilaian keterampilan kognitif bermain bola basket dan didukung oleh hasil angket serta data evaluasi diri siswa yang berpedoman pada tingkatan model pembelajaran TPSR.

Saran

Bagi siswa, agar selalu bersemangat menggali potensi diri dan memahami dengan apa yang dilakukan dalam proses pembelajaran karena akan sangat bermanfaat sekali dalam kehidupan.
Diharapkan penulis lain dapat melakukan penelitian lebih lanjut dengan metode dan permainan yang berbeda sebagai pengembangan dari penelitian ini.

\section{Daftar Pustaka}

Depdiknas. (2003). Undang-Undang RI Nomor 20, Tahun 2003, tentang Sistem Pendidikan Nasional.

Hellison, D. (2003). Teaching responsibility through physical activity. Champaign, USA: Human Kinetics.

Koshy., et al. (2010). What is action research. [Versi elektronik]. Journal of Action Reseacrh in Halthcare, 5.

Lena. (24 Mei 2011). Penjas dan olahraga belum diimplementasikan dalam proses pendidikan karakter. Berita UNY. Diambil pada tanggal 7 Juli 2012, dari http://www.uny.ac.id/berita/UNY/penja s-dan-olahraga-belum-diimplementasikan-dalam-proses-pendidikan-karakter

Mahfudin. (2010). Manfaat beraktivitas fisik setiap hari. Diambil pada tanggal 18 Oktober 2011, dari http://endhine9685.blogspot.com/2010/ 03/manfaat-beraktivitas-fisik-setiaphari.html

Munir, Abdullah. (2010). Pendidikan karakter membangun karakter anak sejak dari rumah. Yogyakarta: Pedagogia.

Rahman, Hari A (2011). Keterlaksanaan pendidikan jasmani dan olahraga di Daerah Istimewa Yogyakarta. Jurnal Pendidikan Jasmani Indonesia, 8(1), 40.

Susana, Tjipto. (2006). Konsep diri positif menentukan prestasi anak. Yogyakarta: Kanisius.

Tjiharjadi, S., Sunjoyo., \& Malinda, M. (2007). To be a great leader. Yogyakarta: Andi Offset. 